\title{
Reversible renal failure after combined treatment with enalapril and frusemide in a patient with congestive heart failure
}

Sir,

Funck-Brentano et al (1986;55:596-8) have reported a case of reversible renal failure occurring in an elderly patient with congestive heart failure after the addition of enalapril to his treatment. We have recently seen two cases of acute renal failure in this setting and two further patients in whom renal impairment developed over a longer period. None had documented hypotension.

Two male patients aged 68 and 66 with histories of longstanding hypertension were admitted with hypertensive left ventricular failure. Initial investigations showed plasma urea concentrations of 14.5 and $14.0 \mathrm{mmol} / 1$ respectively. Both men were treated with frusemide $(80 \mathrm{mg}$ every morning) and enalapril ( $10 \mathrm{mg}$ and $5 \mathrm{mg}$ twice a day respectively). Symptoms and blood pressure were controlled without documented hypotension. Within one month, both were readmitted to hospital with deteriorating renal function, and one patient also had biopsy proven toxic epidermal necrolysis. Peak urea and creatinine concentrations were $21.3 \mathrm{mmol} / 1$ and $303 \mu \mathrm{mol} / 1$ and $42.6 \mathrm{mmol} / 1$ and $772 \mu \mathrm{mol} / 1$ respectively. Medication was withdrawn, but the patient with epidermal necrolysis was treated with oral steroid. Renal function initially improved in both cases, but both patients died-the first suddenly and the second of uraemia (urea $65.5 \mathrm{mmol} / \mathrm{l}$, creatinine $569 \mu \mathrm{mol} / \mathrm{l})$.

We have since seen two further patients with renal impairment after more prolonged treatment with enalapril. One, a woman aged 78 years, had cardiac failure secondary to ischaemic heart disease and aortic regurgitation. The initial plasma urea concentration was $13.9 \mathrm{mmol} / \mathrm{l}$; eight months later it had risen to $23.4 \mathrm{mmol} / 1$ (creatinine $184 \mu \mathrm{mol} / \mathrm{l}$ ). Tender expansion of the finger pulps and koilonychia also developed. Ten days after the withdrawal of enalapril plasma urea was $13.6 \mathrm{mmol} / 1$ and plasma creatinine $160 \mu \mathrm{mol} / \mathrm{l}$. The changes in her finger pulps and nails resolved over several weeks. The other case occurred in a man aged 70 years who had a history of hypertension and arteriopathy. An episode of hypertensive left ventricular failure was controlled with diuretic agents and enalapril; blood urea was $9 \mathrm{mmol} / 1$ and creatinine $149 \mu \mathrm{mol} / 1$. Six months later after readmission with uncontrolled hypertension, left ventricular failure, and oliguria, the blood urea peaked at $65.0 \mathrm{mmol} / 1$ and creatinine at $750 \mu \mathrm{mol} / 1$. Enalapril was withdrawn and the hypertension was controlled with nifedipine and methyldopa. His urine output and uraemia improved over the next two weeks, but he too died suddenly.

The four patients described above all had renal impairment and had been treated with enalapril and diuretic agents for hypertension or left ventricular failure or both. In two renal function deteriorated sharply and they died from renal failure; in the other two the deterioration was less severe. This does not imply a cause and effect relation in these very ill patients, but such a relation cannot be discounted. Cleland et al have reported first dose hypotension with transient renal impairment in a small number of patients with heart failure treated with enalapril ${ }^{1}$ and have predicted on theoretical grounds that long term treatment with enalapril may impair renal function in the absence of hypotension. ${ }^{2}$ FunckBrentano et al have postulated that sodium depletion may be the link between inhibition of angiotensin converting enzyme and renal failure. Irrespective of the mechanism our observations support those of Funck-Brentano et al which lead to the conclusion that caution is needed when enalapril is prescribed in the management of heart failure or in the presence of appreciable renal failure.

James T Stewart,

Doon Lovett,

Michael Joy,

St George's Hospital,

Blackshaw Road,

London SW17 0QT.

\section{References}

1 Cleland JGF, Dargie HJ, McAlpine H, et al. Severe hypotension after first dose enalapril in heart failure. Br Med F 1985;291:1309-12.

2 Cleland JGF, Dargie HJ, Ball SG, et al. Effects of enalapril in heart failure: a double blind study of effects on exercise performance, renal function, hormones, and metabolic state. Br Heart $\mathcal{f} 1985$; 54:305-12. 